\title{
Hubungan Body Image dengan Kepercayaan Diri Remaja Putri
}

\author{
Ifdil Ifdil, Amandha Unzilla Denich, Asmidir Ilyas \\ Jurusan Bimbingan dan Konseling, Fakultas Ilmu Pendidikan, Universitas Negeri Padang, \\ Jl. Prof. Dr. Hamka, Padang, Sumatera Barat, Indonesia 25131 \\ E-mail: ifdil@konselor.org
}

Artikel diterima: 15 Agustus 2017; direvisi 14 September 2017; disetujui 24 September 2017

\begin{abstract}
This study aims to describe the condition of teenage girl's self-confidence and body image and to identify the relationship between teenage girl's body image with selfconfidence. This descriptive and correlation study using 77 teenage girls as sample. Sampling technique used stratified random sampling technique. The research used instrument Zila \& Ifdil Kepercayaan Diri Inventori and Zila \& Ifdil Body Images Inventory. Data were analyzed using descriptive analysis technique and correlational analysis. The findings reveal that teenager girl's self-confidence is generally in the medium category, teenage girl's body image is generally in the neutral category, and there is a significant relationship between teenage girl's body image and their self-confidence. Teenage girl's body image and their self-confidence are important to be increased and developed by counselor, for their better life towards Indonesian golden generation.
\end{abstract}

Keywords: self-confidence; body image; teenage girl

\begin{abstract}
Abstrak: Penelitian ini bertujuan untuk mendeskripsikan kondisi kepercayaan diri dan body image remaja putri serta mengindentifikasi hubungan antara body image dengan kepercayaan diri remaja putri. Penelitian ini merupakan penelitian deskriptif dan korelasional dengan sampel 77 remaja putri. Teknik sampling menggunakan stratified random sampling technique. Penelitian ini menggunakan instrument Zila \& Ifdil Kepercayaan Diri Inventori dan Zila \& Ifdil Body Images Inventory. Data dianalisis dengan menggunakan teknik analisis deskriptif dan analisis korelasional. Penelitian ini mengungkapkan bahwa kondisi kepercayaan diri remaja putri pada umumnya berada pada kategori sedang, kondisi body image remaja putri pada umumnya berada pada kategori netral, dan terdapat hubungan yang signifikan antara body image dengan kepercayaan diri remaja putri. Perlu upaya untuk meningkatkan dan mengembangkan kepercayaan diri dan body image remaja putri oleh konselor untuk kehidupan mereka yang semakin optimal menuju generasi emas Indonesia.
\end{abstract}

Kata kunci: kepercayaan diri; body image; remaja putri

Masa remaja dimulai sekitar usia 10 hingga 13 tahun dan berakhir sekitar usia 18 hingga 22 tahun. Individu yang tergolong remaja akhir cenderung berada dalam keadaan labil dan emosional karena mengalami banyak perubahan-perubahan yang berlangsung cepat (Santrock, 2007). Steinberg (dalam Indri, 2008), mengemukakan bahwa remaja pada usia 15-18 tahun mengalami banyak perubahan secara kognitif, emosional, dan sosial, berpikir lebih kompleks, secara emosional lebih sensitif, serta sering menghabiskan waktu bersama dengan teman-temannya. Pada masa remaja ini juga terjadi berbagai perubahan baik perubahan hormonal, fisik, psikologis maupun sosial. Hal ini relevan dengan pendapat Santrock (2007) yang menyatakan pada masa remaja terjadi proses peralihan perkembangan yang melibatkan perubahan-perubahan dalam diri individu, seperti perubahan biologis, sosio-emosional, dan kognitif. 
Masa puber lebih cepat dialami anak perempuan daripada anak laki-laki. Pengaruh masa puber anak perempuan lebih cepat karena anak perempuan lebih cepat matang dibandingkan anak laki-laki (Hurlock, 1980). Ketika anak perempuan ingin membebaskan diri, mereka mulai ditekan. Perubahanperubahan yang terjadi berakibat pada sikap dan perilaku remaja (Denich \& Ifdil, 2015). Hurlock (1980) menjelaskan salah satu akibat perubahan ini adalah hilangnya kepercayaan diri. Anak remaja yang awalnya sangat yakin pada diri sendiri, menjadi kurang percaya diri dan takut pada kegagalan karena daya tahan fisik menurun dan karena kritik yang bertubi-tubi datang dari orang tua dan teman-temannya (Denich \& Ifdil, 2016). Bahkan, banyak anak laki-laki dan perempuan setelah masa puber mempunyai perasaan rendah diri (Hurlock, 1980).

Kepercayaan diri merupakan suatu keyakinan dalam jiwa manusia bahwa tantangan hidup apapun harus dihadapi dengan berbuat sesuatu (Angelis, 2003). Kepercayaan diri berarti mengapresiasi dan menilai diri sendiri (Utomo \& Harmiyanto, 2016). Kepercayaan diri itu lahir dari kesadaran bahwa jika memutuskan untuk melakukan sesuatu, maka sesuatu itu pula yang harus dilakukan. Kepercayaan diri itu akan datang dari kesadaran individu bahwa individu tersebut memiliki tekad untuk melakukan apapun, sampai tujuan yang ia inginkan tercapai. Fatimah (2006) menjelaskan bahwa kepercayaan diri adalah sikap positif seorang individu yang memampukan dirinya untuk mengembangkan penilaian positif, baik terhadap diri sendiri maupun terhadap lingkungan/situasi yang dihadapinya. Idealnya kepercayaan diri yang dimiliki individu haruslah berada pada kategori sangat tinggi. Hal ini dimaksud seorang individu untuk mengembangkan aspek-aspek yang ada dalam dirinya membutuhkan kepercayaan diri tinggi. Namun, kenyataan yang ada di lapangan masih banyak individu, terutama remaja yang memiliki kepercayaan diri rendah.

Hasil penelitian Farida (2014) menunjukkan 25\% kepercayaan diri remaja berada pada kategori sedang, $75 \%$ kepercayaan diri remaja berada pada kategori rendah. Selanjutnya, penelitian oleh Adiasih (2015) menunjukkan 9,7\% kepercayaan diri siswa berada pada kategori sangat tinggi, 24,2\% berada pada kategori tinggi, 37,1\% berada pada kategori sedang, 22,6\% berada pada kategori rendah, dan $6,5 \%$ berada pada kategori sangat rendah. Dari hasil penelitian yang telah dilakukan terlihat kepercayaan diri remaja berada pada kategori sedang bahkan tergolong rendah.

Rendahnya kepercayaan diri pada remaja disebabkan oleh beberapa faktor. Santrock (2003) menjelaskan salah satu faktor yang memengaruhi kepercayaan diri adalah penampilan fisik. Perubahan fisik menimbulkan dampak psikologis yang tidak diinginkan. Mayoritas anak muda lebih banyak memerhatikan penampilan mereka dibanding aspek lain dalam diri mereka, dan banyak di antara mereka yang tidak suka melihat apa yang mereka lihat di cermin. Anak perempuan memiliki perasaan tidak suka yang lebih tinggi dibandingkan anak laki-laki, hal ini mencerminkan penekanan kultural yang lebih besar terhadap atribut fisik wanita (Papalia, Old, \& Feldman, 2008).

Munculnya penilaian di kalangan remaja putri bahwa standar tubuh saat ini yang mementingkan penampilan fisik dengan bentuk tubuh yang proposional, telah membuat remaja putri saat ini menjadi kurang percaya diri, remaja putri selalu menilai dirinya melalui kaca mata orang lain yaitu temanteman sepergaulannya (Ratnawati, 2012). Berawal dari penampilan fisik, remaja mulai memberikan gambaran dan persepsi tentang bentuk fisik yang dimiliki, kemudian beranjak pada penampilan fisik yang dimiliki orang lain hingga standar tubuh yang harus dimiliki setiap perempuan (Denich \& Ifdil, 2015). Gambaran dan persepsi tentang penampilan fisik inilah yang disebut body image.

Body image merupakan imajinasi subyektif yang dimiliki seseorang tentang tubuhnya, khususnya yang terkait dengan penilaian orang lain, dan seberapa baik tubuhnya harus disesuaikan dengan persepsi-persepsi ini (Arthur \& Emily, 2010). Sejalan dengan itu, Smolak \& Thompson (2009) menjelaskan bahwa tingkat body image individu digambarkan dengan seberapa jauh individu merasa puas terhadap bagian-bagian tubuh dan penampilan fisik secara keseluruhan serta menambahkan tingkat penerimaan citra raga sebagian besar tergantung pada pengaruh sosial budaya yang terdiri dari empat aspek yaitu: reaksi orang lain, perbandingan dengan orang lain, peranan individu dan identifikasi terhadap orang lain. Idealnya body image yang harus dimiliki individu adalah positif, 
agar ia mampu menerima dirinya sendiri tanpa harus memikirkan standar tubuh kebanyakan orang. Namun, yang terlihat di lapangan masih banyaknya siswa terutama remaja putri yang memiliki body image negatif baik itu pada kategori rendah maupun kategori sedang.

Pada penelitian yang dilakukan oleh Alidia (2014) menunjukkan body image siswa perempuan lebih rendah dibandingkan dengan body image siswa laki-laki. Selanjutnya, hasil penelitian Putri (2015) menunjukkan body image yang dimiliki siswa berada pada kategori sedang yang artinya cukup positif.

Wawancara yang dilakukan dengan remaja putri yang berinisial AM pada 20 Januari 2017 menyatakan bentuk tubuh yang dimilikinya saat ini sangatlah tidak ideal dibandingkan remaja putri lainnya. Ini berarti AM memiliki body image yang negatif terhadap dirinya. Akibatnya AM memiliki kepercayaan diri yang rendah ketika keluar rumah atau berada di tempat yang ramai. AM harus memikirkan penampilannya agar tidak terlihat begitu buruk di antara orang-orang yang memiliki tubuh yang ideal. Hasil wawancara dengan siswa Sekolah Menengah Atas (SMA) yang berinisial AS pada 25 januari 2017 melalui sosial media juga menyatakan hal yang sama. Baginya tubuh yang ideal itu adalah tubuh yang memiliki berat dan tinggi badan yang seimbang, serta bentuk tubuh yang proposional. Namun AS merasa tubuh yang dimilikinya saat ini sangat jauh dengan apa yang diharapkannya. Hal ini terlihat siswa memiliki body image yang negatif terhadap dirinya sendiri.

Tujuan penelitian yang ingin dicapai adalah: (1) mendeskripsikan kondisi kepercayaan diri remaja putri; (2) mendeskripsikan kondisi body image remaja putri; (3) mengidentifikasi hubungan body image dengan kepercayaan diri remaja putri

\section{METODE}

Penelitian ini merupakan penelitian deskriptif (Smith, 2015; Best \& Kahn, 2016) dan korelasional (Bordens \& Abbott, 2002; Miller, 2017) dengan sampel sebanyak 77 remaja putri. Pemilihan sampel menggunakan teknik purposive stratified random sampling (Cochran, 2007; Shields \& Twycross, 2008). Instrumen penelitian menggunakan Zila \& Ifdil Kepercayaan Diri Inventori (ZIKDI) dengan $\alpha$ 0,89 reliabilitas item dan Zila \& Ifdil Body Images Inventory (ZI-BII) dengan $\alpha$ 0,90. Data yang diperoleh dianalisis dengan menggunakan teknik analisis deskriptif (Scott, 2017) dan analisis korelasional (Moser \& Kalton, 2017) dengan bantuan SPSS versi 20.

\section{HASIL}

Kondisi kepercayaan diri remaja putri pada umumnya berada pada kategori sedang dengan frekuensi sebanyak 28 orang (36\%), kategori rendah sebanyak 21 orang (27\%), kategori tinggi sebanyak 20 orang $(26 \%)$, kategori sangat tinggi sebanyak 6 orang $(8 \%)$, dan kategori sangat rendah sebanyak 2 orang $(3 \%)$. Temuan ini mengungkapkan kondisi kepercayaan diri remaja putri pada umumnya berada pada kategori sedang.

Kondisi body image remaja putri pada umumnya berada pada kategori netral dengan frekuensi 39 orang $(51 \%)$, kategori positif sebesar 13 orang (17\%), kategori negatif sebesar 12 orang (16\%), kategori sangat positif sebesar 7 orang (9\%), dan kategori sangat negatif sebesar 6 orang (8\%). Temuan ini mengungkapkan secara umum kondisi body image remaja putri berada pada kategori netral.

Dari hasil temuan diperoleh korelasi antara body image dengan kepercayaan diri menggunakan bantuan SPSS. Nilai koefisien korelasi sebesar 0.788 dengan taraf signifikansi dua jalur sebesar 0,000 pada tingkat taraf kepercayaan 0,01 . Dari hasil perhitungan diperoleh nilai signifikansi dua jalur sebesar $0,000<0,01$. Maka dapat disimpulkan $\mathrm{H}_{1}$ diterima. Artinya, terdapat hubungan yang signifikan antara body image dengan kepercayaan diri remaja putri. 


\section{PEMBAHASAN}

Berdasarkan hasil penelitian, kondisi kepercayaan diri remaja putri pada umumnya berada pada kategori sedang. Ini mengungkapkan masih adanya remaja putri yang belum mampu bersikap positif terhadap dirinya sendiri dan kemampuan yang dimilikinya. Ini sejalan dengan pendapat tentang kepercayaan diri yaitu sikap positif individu yang memampukan dirinya untuk mengembangkan penilaian positif, baik terhadap diri sendiri maupun lingkungannya (Fatimah, 2006). Sedangkan pada hasil penelitian berbanding terbalik dengan bentuk kepercayaan diri yang semestinya.

Hal ini dapat dipengaruhi oleh beberapa faktor, baik itu dari segi fisik, maupun lingkungan yang menjadikan remaja tidak memiliki kepercayaan diri. Santrock (2003) mengungkapkan kepercayaan diri dipengaruhi oleh beberapa faktor, yaitu: penampilan fisik, konsep diri, hubungan dengan orang tua, dan hubungan dengan teman sebaya. Selanjutnya, Hakim (2002) menjelaskan sumber penyebab timbulnya rasa tidak percaya diri, antara lain: cacat atau kelainan fisik, buruk rupa, ekonomi lemah, status sosial, status perkawinan, sering gagal, kalah bersaing, kurang cerdas, pendidikan rendah, perbedaan lingkungan, tidak supel, tidak siap menghadapi situasi tertentu, sulit menyesuaikan diri, mudah cemas dan penakut, tidak terbiasa, mudah gugup, bicara gagap, pendidikan keluarga kurang baik, sering menghindar, mudah menyerah, tidak bisa menarik simpati orang, dan kalah wibawa dengan orang lain.

Dari pernyataan di atas, salah satu yang memengaruhi kepercayaan diri adalah penampilan fisik atau bentuk tubuh yang dimilikinya. Penampilan fisik yang sangat berpengaruh pada kepercayaan diri didasarkan bagaimana individu tersebut melihat bagaimana kondisi fisik yang dapat berupa bentuk tubuh ataupun berat tubuh yang ia miliki serta bagaimana penilaian individu itu terhadap fisik yang ia miliki dan bagaimana bentuk yang ia inginkan (Surya, 2007). Kepercayaan diri merupakan suatu keyakinan seseorang terhadap segala aspek yang ada pada dirinya dan diwujudkan dalam tingkah laku sehari-hari serta bagaimana individu mampu menilai diri sendiri dan lingkungannya secara positif. Hal demikian sejalan dengan hasil penelitian Suhardita (2011) bahwa kepercayaan diri dapat dibentuk melalui pengalaman yang pernah dilakukan individu baik dalam lingkungan sekolah dan sehari-hari dan diwujudkan dalam tingkah laku. Beberapa cara yang terbukti manjur meningkatkan kepercayaan diri adalah layanan konseling kelompok (Imro'atun, 2017) dan selfinstruction (Fiorentika, Santoso, \& Simon, 2016)

Berdasarkan hasil penelitian, tingkat body image remaja putri pada umumnya berada pada kategori netral. Hasil penelitian mengungkapkan masih adanya remaja putri yang belum sepenuhnya memiliki body image yang positif. Grogan dalam Nahdiyah (2015) menyatakan body image dapat didefinisikan sebagai persepsi, pikiran, perasaan seseorang terhadap tubuhnya sendiri. Charles \& Kerr dalam Davista (2016) menemukan bahwa kebanyakan wanita tidak puas dengan body image mereka. Body image yang negatif ini memacu wanita untuk memperbaiki penampilan mereka. Kebanyakan remaja putri mengungkapkan ketidaknyamanan akan bentuk tubuhnya dan ingin menurunkan berat badannya. Ketidakpuasan akan bentuk tubuh lebih banyak dialami oleh remaja putri dibandingkan remaja putra, hal tersebut dapat disebabkan dari berbagai macam hal, seperti keluarga teman sepermainan, serta media (Sari, 2001). Hal yang dapat diakibatkan dari adanya ketidakpuasan akan bentuk tubuh pun bermacam-macam, salah satu diantaranya adalah rendahnya kepercayaan diri.

Menurut Santrock (2003) di masa remaja atau pubertas, remaja putri terlihat lebih tidak puas dan memiliki citra tubuh yang negatif dibandingkan dengan remaja laki-laki. Hal tersebut dikarenakan adanya kemungkinan meningkatnya body fat pada remaja putri, sedangkan remaja laki-laki lebih merasa puas akan bentuk tubuhnya karena di masa inilah otot-otot mereka mulai terlihat. Menurut Furnham, Badmin, \& Sneade (2002) "the female ideal is to be extremely thin, with the emphasis placed on slim hips, bottom, and thighs: Bentuk tubuh ideal perempuan adalah sangat ramping, dengan penekanan pada pinggul yang langsing, pantat dan paha".

Perhitungan koefisien korelasi dihitung menggunakan teknik analisis Pearson Correlation dengan bantuan SPSS menunjukkan bahwa terdapat hubungan yang signifikan antara body image dengan kepercayaan diri. Hubungan ini juga merupakan hubungan yang positif, artinya semakin 
positif body image remaja putri, maka semakin tinggi kepercayaan diri yang dimiliki. Terlihat jelas pengaruh yang sangat kuat dari body image dalam hal ini penampilan fisik, terhadap kepercayaan diri remaja putri terutama saat berada di depan umum, bagaimana menampilkan kemampuan yang dimiliki tanpa harus terpengaruh oleh orang lain.

Sejalan dengan itu, sejumlah peneliti telah menemukan bahwa penampilan fisik merupakan suatu kontributor yang sangat berpengaruh pada rasa percaya diri remaja (Adams, dkk. dalam Santrock, 2003). Penampilan fisik yang sangat berpengaruh pada kepercayaan diri didasarkan bagaimana individu tersebut melihat bagaimana kondisi fisik yang dapat berupa bentuk tubuh ataupun berat tubuh yang ia miliki serta bagaimana penilaian invidu itu terhadap fisik yang ia miliki dan bagaimana bentuk yang ia inginkan.

Kristiawan (2006) menjelaskan bahwa body image remaja putri banyak dipengaruhi oleh persepsi tentang standar tubuh yang sedang tren di kalangan remaja saat ini. Kemudian remaja mulai berlomba-lomba menyesuaikan tubuhnya dengan tren itu tanpa memandang baik buruk terhadap tubuhnya (Violina, 2013). Inilah yang kemudian menjadikan body image remaja semakin lama semakin negatif (Lingga, 2011). Hal ini sejalan dengan pengertian body image (Arthur \& Emily, 2010) yaitu imajinasi subyektif yang dimiliki seseorang tentang tubuhnya, khususnya yang terkait dengan penilaian orang lain, dan seberapa baik tubuhnya harus disesuaikan dengan persepsipersepsi ini.

Akibat persepsi tubuhnya yang semakin buruk, remaja semakin tidak percaya diri baik itu pada penampilan di depan umum maupun kemampuan terhadap dirinya sendiri. Tentu saja ini berbanding terbalik dengan teori yang dikemukakan oleh Surya (2009) yang menyatakan seseorang akan percaya diri ketika orang tersebut menyadari bentuk tubuhnya yang sangat ideal dan orang tersebut merasa puas melihat bentuk tubuhnya, maka body image yang terbentuk pun menjadi positif.

Remaja putri yang memandang tubuhnya tidak ideal seperti wajahnya kurang menarik, badannya terlalu gemuk atau kurus dan lain sebagainya, mereka menjadi sibuk memikirkan kondisi fisiknya, sehingga body image yang terbentuk menjadi negatif dan dapat dikatakan tidak memiliki kepercayaan diri. Temuan tersebut sejalan dengan hasil penelitian yang dilakukan oleh Marita, Yuliadi, \& Karyanta (2014) dimana didapatkan ada hubungan positif antara body image dengan kepercayaan diri yang artinya semakin tinggi body image maka semakin tinggi tingkat kepercayaan dirinya, demikian juga sebaliknya. Dari penelitian ini didapatkan citra tubuh (body image) seseorang dapat memengaruhi tingkat kepercayaan dirinya.

\section{SIMPULAN}

Berdasarkan penelitian yang dilakukan, dapat disimpulkan kondisi kepercayaan diri remaja putri pada umumnya berada pada kategori sedang, kondisi body image remaja putri pada umumnya berada pada kategori netral, dan terdapat hubungan yang signifikan antara body image dengan kepercayaan diri remaja putri dimana semakin positif body image remaja putri, maka semakin tinggi kepercayaan diri remaja putri. Perlu upaya untuk mengembangan dan meningkatkan kepercayaan diri dan body image remaja putri oleh Guru Bimbingan dan Konseling/Konselor melalui layanan bimbingan dan konseling, serta diperlukan penelitian lanjut pada aspek spesifik body image dan kepercayaan diri remaja putri.

\section{DAFTAR RUJUKAN}

Adiasih, L. (2015). Hubungan Antara Pola Asuh Orang Tua dengan Kepercayaan Diri Siswa di SMAN 1 Tarusan. Universitas Negeri Padang.

Alidia, F. (2014). Body Image Siswa Ditinjau dari Gender dan Implikasinya Terhadap Layanan Bimbingan dan Konseling. Universitas Negeri Padang.

Angelis, B. De. (2003). Confidence: Percaya Diri Sumber Sukses dan Kemandirian. Jakarta: PT. Gramedia Pustaka.

Arthur, S. R., \& Emily, S. R. (2010). Kamus Psikologi. Yogyakarta: Pustaka Pelajar. 
Best, J. W., \& Kahn, J. V. (2016). Research in Education. Pearson Education India.

Bordens, K. S., \& Abbott, B. B. (2002). Research Design and Methods: A Process Approach. McGraw-Hill.

Cochran, W. G. (2007). Sampling Techniques. John Wiley \& Sons.

Davista, O. A. (2016). Perbedaan Body Image Ditinjau dari Tahap Perkembangan (Remaja dan Dewasa Awal) dan Jenis Kelamin (Perempuan dan Laki-Laki) di Kelurahan Banyumanik Kecamatan Banyumanik Kota Semarang. Universitas Kristen Satya Wacana.

Denich, A. U., \& Ifdil, I. (2015). Konsep Body Image Remaja Putri. Jurnal Konseling dan Pendidikan, 3(2), 55-61. Diambil dari http://jurnal.konselingindonesia.com/index.php/jkp/article/view/165

Denich, A. U., \& Ifdil, I. (2016). Konsep Kepercayaan Diri Remaja Putri. Jurnal EDUCATIO: Jurnal Pendidikan Indonesia, 2(2), 35-42.

Farida, N. I. (2014). Upaya Meningkatkan Kepercayaan Diri Siswa Remaja Putri yang Mengalami Pubertas Awal Melalui Layanan Penguasaan Konten dengan Teknik Role Playing di Kelas VII SMP N 13 Semarang Tahun Ajaran 2013/2014. Universitas Negeri Semarang.

Fatimah, E. (2006). Psikologi Perkembangan (Perkembangan Peserta Didik). Bandung: Pustaka Setia, 142.

Fiorentika, K., Santoso, D. B., \& Simon, I. M. (2016). Keefektifan Teknik Self-Instruction untuk Meningkatkan Kepercayaan Diri Siswa SMP. Jurnal Kajian Bimbingan dan Konseling, 1(3), 104-111. http://dx.doi.org/10.17977/um001v1i32016p104

Furnham, A., Badmin, N., \& Sneade, I. (2002). Body Image Dissatisfaction: Gender Differences in Eating Attitudes, Self-Esteem, and Reasons for Exercise. The Journal of Psychology, 136(6), 581-596. http://dx.doi.org/10.1080/00223980209604820

Hakim, T. (2002). Mengatasi Rasa Tidak Percaya Diri. Jakarta: Puspa Swara.

Hurlock, E. B. (1980). Psikologi Perkembangan. Jakarta: Erlangga.

Imro'atun, S. (2017). Keefektifan Layanan Konseling Kelompok untuk Meningkatkan Kepercayaan Diri Siswa Sekolah Menengah Pertama. Jurnal Kajian Bimbingan dan Konseling, 2(2), 50-57. http://dx.doi.org/10.17977/um001v2i22017p050

Indri, K. N. (2008). Stress pada Remaja. Universitas Sumatera Utara.

Kristiawan, A. (2006). Menjelajah Tubuh: Perempuan dan Mitos Kecantikan. PT LKiS Pelangi Aksara.

Lingga, M. (2011). Studi tentang Pengetahuan Gizi, Kebiasaan Makan, Aktivitas Fisik, Status Gizi dan Body Image Remaja Putri yang BerstatusGizi Normal dan Gemuk/Obes di SMA Budi Mulia Bogor. Institut Pertanian Bogor. Diambil dari http://repository.ipb.ac.id/ handle/123456789/54351

Marita, G. A. D., Yuliadi, I., \& Karyanta, N. A. (2014). Hubungan antara Body Image dan Imaginary Audience dengan Kepercayaan Diri pada Siswi Kelas X SMA Negeri 2 Nganjuk. Jurnal Ilmiah Psikologi Candrajiwa, 3(3 Des). Diambil dari http://candrajiwa.psikologi.fk.uns.ac.id/index. $\mathrm{php} /$ candrajiwa/article/view/86

Miller, S. A. (2017). Developmental Research Methods. Sage Publications.

Moser, C. A., \& Kalton, G. (2017). Survey Methods in Social Investigation. Routledge.

Nahdiyah, I. (2015). Hubungan antara Body Image dengan Kepuasan Hidup pada Remaja yang Mengalami Obesitas di Komunitas KAGUMI (Ikatan Wanita Gemuk Indonesia). Universitas Islam Negeri Maulana Malik Ibrahim Malang.

Papalia, D. E., Old, S. W., \& Feldman, R. D. (2008). Human Development (Psikologi Perkembangan) edisi kesembilan. Jakarta: Kencana Prenada Media Group.

Putri, T. A. (2015). Hubungan antara Body Image dengan Kepercayaan Diri Mahasiswi yang 
Mengalami Obesitas. Universitas Muhammadiyah Surakarta.

Ratnawati, V. (2012). Percaya Diri, Body Image dan Kecenderungan Anorexia Nervosa pada Remaja Putri. PERSONA: Jurnal Psikologi Indonesia, 1(2). Diambil dari http://jurnal.untag-sby.ac.id/ index.php/persona/article/view/39

Santrock, J. W. (2003). Adolescence: Perkembangan Remaja. Erlangga. Jakarta.

Santrock, J. W. (2007). Remaja jilid 2. Jakarta: Erlangga.

Sari, A. O. (2001). Identifikasi Faktor Penyebab Body Dissatisfaction dengan Coping Behavior yang dipilih oleh Remaja Putri Usia 16-18 Tahun di SMU Yayasan Pendidikan dan Pengajaran Indonesia I Surabaya. Fakultas Psikologi . Diambil dari http://repository.ubaya.ac.id/3985/

Scott, J. (2017). Social Network Analysis. Sage.

Shields, L., \& Twycross, A. (2008). Sampling in Quantitative Research. Paediatric Nursing, 20(5), 37.

Smith, J. A. (2015). Qualitative Psychology: A Practical Guide to Research Methods. Sage.

Smolak, L. E., \& Thompson, J. (2009). Body Image, Eating Disorders, and Obesity in Youth: Assessment, Prevention, and Treatment. American Psychological Association.

Suhardita, K. (2011). Efektivitas Penggunaan Teknik Permainan dalam Bimbingan Kelompok untuk Meningkatkan Percaya Diri Siswa (Penelitian Quasi Eksperimen pada Sekolah Menengah Atas Laboratorium (Percontohan) UPI Bandung Tahun Ajaran 2010/2011). ABMAS, Edisi Khusus(1), 127-138. Diambil dari http://jurnal.upi.edu/file/12-Kadek_Suhardita.pdf

Surya, H. (2007). Percaya Diri Itu Penting. Elex Media Komputindo.

Surya, H. (2009). Menjadi Manusia Pembelajaran. Elex Media Komputindo.

Utomo, D. P., \& Harmiyanto, H. (2016). Hubungan Keterampilan Komunikasi Interpersonal dan Kepercayaan Diri Siswa Kelas X SMAN 1 Garum Kabupaten Blitar. Jurnal Kajian Bimbingan dan Konseling, 1(2), 55-59. http://dx.doi.org/10.17977/um001v1i22016p055

Violina, E. I. (2013, Agustus 23). Pengaruh Penggunaan Teknik Assertive Training dalam Mereduksi Perilaku Konsumtif pada Siswa SMPN 2 Delitua Tahun Ajaran 2013/2014. Universitas Negeri Medan. Diambil dari http://digilib.unimed.ac.id/7300/ 